\title{
Glosa do WYROKU WoJEWÓDZKIEGo SĄDU AdministracyJNEgo WE WrocŁaWiU Z DNIA 22 LIPCA 2019 R., SYGN. I SA/WR 365/19
}

Streszczenie. Glosa omawia wyrok Wojewódzkiego Sądu Administracyjnego we Wrocławiu, w którym po raz pierwszy wyraźnie sprzeciwiono się praktyce instrumentalnego wszczynania postępowań karnych skarbowych w celu zawieszenia biegu terminu przedawnienia zobowiązań podatkowych. Sąd doszedł do wniosku, co jest istotnym novum, że zasadność wszczęcia postępowania karnego skarbowego nie może pozostawać poza kontrolą sądową. W wyroku rozwinięto również zagadnienie nadużycia prawa przez organy podatkowe, które to nadużycie stało się podstawą do uchylenia zaskarżonej decyzji, oraz zaproponowano uniwersalny test nadużycia prawa przez organy podatkowe. W związku z tym autor wyraził nadzieję, że wyrok ten będzie przełomowy, a sądy administracyjne coraz częściej zaczną kwestionować praktyki organów mające znamiona nadużycia prawa.

Słowa kluczowe: bieg terminu przedawnienia, postępowanie karne skarbowe, nadużycie prawa, zawieszenie biegu terminu przedawnienia

Wyrokiem z dnia 22 lipca 2019 r. Wojewódzki Sąd Administracyjny (WSA) we Wrockawiu w sprawie o sygnaturze akt I SA/Wr 365/19 orzekł, że nie może pozostać poza kontrolą sądową kwestia zasadności zawieszenia biegu terminu przedawnienia w związku z wszczęciem

* Prawnik w Mariański Group Kancelarii Prawno-Podatkowej, e-mail: lporada@ marianskigroup.pl.

${ }^{1}$ Wyrok WSA we Wrocławiu z dnia 22 lipca 2019 r., sygn. I SA/Wr 365/19, LEX nr 2725718. 


\section{postępowania karnego skarbowego przez organ podatkowy pierwszej instancji, działający jako organ przygotowawczy w sprawach o przestęp- stwa skarbowe i wykroczenia skarbowe.}

\section{STANOWISKa STRON SPORU}

Sprawa dotyczyła zobowiązania podatkowego spółki z ograniczoną odpowiedzialnością (dalej: Spółka lub Skarżąca) w podatku od towarów i usług za okres styczeń-wrzesień 2013 r. Postępowanie zostało wszczęte w październiku 2016 r. przez Dyrektora Urzędu Kontroli Skarbowej, który po przeprowadzonym postępowaniu podatkowym wydał doręczoną w październiku 2017 r. decyzję. W decyzji organ zakwestionował prawo podatnika do zastosowania pięcioprocentowej stawki podatku od towarów i usług przy sprzedaży produktów przygotowanych w ramach usług gastronomicznych prowadzonych w sieciach restauracji, uznając, że prawidłowa stawka podatku od towarów i usług wynosi $8 \%$. Ponadto organ podatkowy pierwszej instancji, działając jako organ przygotowawczy w sprawie o przestępstwo skarbowe, wszczął w listopadzie 2017 r. postępowanie karne skarbowe w sprawie podania przez Spółkę nieprawdy w korektach deklaracji w podatku od towarów i usług, doręczając Skarżącej stosowne zawiadomienie dnia 5 grudnia 2017 r. Spółka wniosła odwołanie od decyzji, na mocy którego organ odwoławczy decyzją wydaną już w 2018 r. uchylił decyzję organu pierwszej instancji i przekazał sprawę do ponownego rozpoznania, podnosząc brak rozstrzygnięcia $\mathrm{w}$ przedmiocie zwolnienia $\mathrm{z}$ podatku na podstawie art. $14 \mathrm{~m} \$ 3$ Ordynacji podatkowej ${ }^{2}$. Po ponownym przeprowadzeniu postępowania organ pierwszej instancji powtórzył swoje stanowisko, a po wniesieniu odwołania organ odwoławczy decyzją wydaną w 2019 r. utrzymał w mocy decyzję organu podatkowego pierwszej instancji.

Organ podatkowy stwierdził, powołując się na uchwałę 7 sędziów Naczelnego Sądu Administracyjnego (NSA) z dnia 29 czerwca 2009 r., sygn. I FPS 9/08, że wskutek złożenia w marcu 2016 r. korekty deklaracji w podatku od towarów i usług termin biegu przedawnienia rozpoczął się z dniem 1 stycznia 2017 r., a skończy się z dniem 31 grudnia 2021 r. Ponadto podniesiono kwestię wszczęcia przygotowawczego postępowania karnego skarbowego wobec Spółki, o czym została ona poinformowana. Zgodnie

${ }^{2}$ Ustawa z dnia 29 sierpnia 1997 r. - Ordynacja podatkowa (tekst jedn. Dz.U. z 2017 r., poz. 201), dalej: o.p. 
bowiem $\mathrm{z}$ art. $70 \$ 6$ pkt 1 o.p. bieg terminu przedawnienia zobowiązania podatkowego nie rozpoczyna się, a rozpoczęty ulega zawieszeniu, z dniem wszczęcia postępowania $\mathrm{w}$ sprawie o przestępstwo skarbowe lub wykroczenie skarbowe, o którym podatnik został zawiadomiony, jeżeli podejrzenie popełnienia przestępstwa lub wykroczenia wiąże się z niewykonaniem tego zobowiązania. Z kolei, jak wskazuje art. 70c o.p., organ podatkowy właściwy w sprawie zobowiązania podatkowego, z którego niewykonaniem wiąże się podejrzenie popełnienia przestępstwa skarbowego lub wykroczenia skarbowego, zawiadamia podatnika o nierozpoczęciu lub zawieszeniu biegu terminu przedawnienia zobowiązania podatkowego w przypadku, o którym mowa w art. $70 \$ 6$ pkt 1 o.p., najpóźniej z upływem terminu przedawnienia, o którym mowa $\mathrm{w}$ art. $70 \$ 1$ o.p., oraz o rozpoczęciu lub dalszym biegu terminu przedawnienia po upływie okresu zawieszenia.

Z kolei podatnik podnosił naruszenie przez organ art. $70 \$ 6$ i 7 o.p. oraz art. $70 \$ 1$ o.p. poprzez ich błędną wykładnię, co doprowadziło do niezastosowania przepisów art. $233 \$ 1$ pkt 2 lit. a o.p. w zw. z art. $208 \$ 1$ o.p., stanowiących o umorzeniu postępowania podatkowego, gdy stanie się ono z jakiejkolwiek przyczyny bezprzedmiotowe. Skarżący twierdził bowiem, że organ odwoławczy powinien decyzję organu pierwszej instancji uchylić w całości i umorzyć postępowanie w sprawie ze względu na wygaśnięcie zobowiązania podatkowego wskutek upływu terminu przedawnienia. Spółka miała działać w warunkach nieumyślności, a organ podatkowy, wszczynając w tej sprawie postępowanie karne skarbowe, nadużył swoich kompetencji. W osobnym piśmie procesowym powołano się na wyrok Wojewódzkiego Sądu Administracyjnego we Wrocławiu z dnia 17 maja 2019 r. ${ }^{3}$, w którym potwierdzono, że sprzedaż produktów z okienek zewnętrznych drive in, walk through, food court i wewnątrz punktów sprzedaży stanowi dostawę towarów opodatkowaną pięcioprocentową stawką podatku od towarów i usług.

\section{RozstrzygniĘCIE WSA We WrocŁaWiU}

Wojewódzki Sąd Administracyjny we Wrocławiu uwzględnił skargę na decyzje Dyrektora Izby Administracji Skarbowej oraz Naczelnika Urzędu Celno-Skarbowego i umorzył postępowanie podatkowe. Sąd nie oceniał merytorycznie skargi, ponieważ uznał, że na skutek nadużycia prawa

\footnotetext{
3 Sygn. I SA/Wr 58/19, LEX nr 2676586.
} 
przez organ podatkowy zobowiązanie uległo przedawnieniu. Stwierdzono, że organ podatkowy wszczął postępowanie karne skarbowe w celu innym niż cel tego postępowania, tj. wyłącznie w celu zawieszenia biegu terminu przedawnienia zobowiązania podatkowego, w związku z czym naruszono art. $70 \$ 1$ o.p. oraz art. $70 \$ 6$ pkt 1 o.p. Działanie takie miało być sprzeczne $\mathrm{z}$ konstytucyjną zasadą demokratycznego państwa prawa oraz wywodzonych z niej zasad praworządności, pewności prawa, uzasadnionych oczekiwań, prawa do dobrej administracji oraz prowadzenia postępowania w sposób budzący zaufanie do organów podatkowych.

Sąd w uzasadnieniu przeanalizował przepisy rangi konstytucyjnej i ustawowej, orzecznictwo Trybunału Sprawiedliwości Unii Europejskiej (TSUE) i Trybunału Konstytucyjnego, w konsekwencji czego doszedł do wniosku, że rozpatrujący sprawę sąd musi posiadać jurysdykcję do zbadania wszystkich kwestii faktycznych i prawnych mających istotne znaczenie dla przedstawionego mu do rozstrzygnięcia sporu, a ponadto, że naruszeniem art. 6 ust. 1 Konwencji o ochronie praw człowieka i podstawowych wolności byłoby związanie sądu uprzednimi ustaleniami organów administracyjnych, bez ich niezależnego badania. Prowadziło to do wniosku, że poza kontrolą sądową nie może pozostać kwestia zasadności zastosowania przez organy podatkowe art. $70 \$ 6$ pkt 1 o.p., co wojewódzkie sądy administracyjne są obowiązane badać z urzędu, a Naczelny Sąd Administracyjny na zarzut.

Następnie stwierdzono, że czynności podejmowane przez organy podatkowe, jako wykonywane na podstawie i w granicach prawa, nie mogą być wykonywane niezgodnie z ich celem. Rolą sądów powinno być przeciwdziałanie nadużywaniu prawa zwłaszcza wtedy, gdy dokonywane jest przez organ władzy. Zauważono także, że formalne działanie organów podatkowych kwalifikowane jako nadużycie prawa nie może wywołać skutku korzystnego dla działającego. Skonstruowano w ten sposób swoisty test nadużycia: czy w sytuacji, gdyby nie istniał przepis art. $70 \$ 6$ pkt 1 o.p., organy skarbowe dokonałyby wszczęcia postępowania karnego skarbowego. Odpowiedź negatywna świadczyłaby o nadużyciu prawa przez organ skarbowy.

Ponadto w opinii Sądu Skarżąca nie została powiadomiona o wszystkich przyczynach wszczęcia śledztwa, co nie pozwalało jej prawidłowo sformułować skargi. Nie zgodzono się w ten sposób z uchwałą Naczelnego Sądu Administracyjnego ${ }^{4}$, w myśl której czynności podjęte przez organ

${ }^{4}$ Uchwała NSA z dnia 18 czerwca 2018 r., sygn. I FPS 1/18, ONSAiWSA 2018, nr 6, poz. 96. 
podatkowy były wystarczające do osiągnięcia celu, jakim jest zawieszenie biegu terminu przedawnienia zobowiązania podatkowego. $\mathrm{W}$ ten sposób zarówno naruszono prawo do obrony podatnika, jak i nie dano szansy sądowi na zweryfikowanie legalności działań organu podatkowego.

3. Komentarz

W minionych latach sądy administracyjne wydawały znaczącą liczbę orzeczeń dotyczących zawieszenia biegu terminu przedawnienia zobowiązania podatkowego w związku ze wszczęciem postępowania karnego skarbowego. Choć w zdecydowanej większości dotyczyły one spraw pobocznych, związanych z kwestiami technicznymi i proceduralnymi, do dzisiaj nie zostały wyjaśnione liczne wątpliwości związane ze stosowaniem art. 70 $\$ 6$ pkt 1 o.p. Warto też zwrócić uwagę, że znaczna część wyroków jest krytykowana przez doktrynę, jako praktycznie niestawiających organom podatkowym wymogów związanych z procesem stosowania prawa pomimo nieprzemijających, poważnych wątpliwości co do zasadności oraz sposobu korzystania $\mathrm{z}$ instytucji zawieszenia biegu terminu przedawnienia zobowiązań podatkowych. Naczelny Sąd Administracyjny wypowiedział się $\mathrm{w}$ ostatnich latach choćby $\mathrm{w}$ przedmiocie tego, czy bieg terminu przedawnienia zobowiązania podatkowego zawiesza wszczęcie postępowania w sprawie (in rem) czy przeciwko osobie (in personam $)^{5}$, komu należy doręczać zawiadomienie o zawieszeniu biegu terminu przedawnienia ${ }^{6}$ oraz jakie elementy musi zawierać takie zawiadomienie.

Odnosząc się już do treści glosowanego orzeczenia, autor w całej rozciągłości zgadza się z wnioskami, do jakich doszedł Wojewódzki Sąd Administracyjny we Wrocławiu. Jak wielu innych komentatorów, autor wyraża podziw dla uzasadnienia składającego się z wielu źródeł, do których odwołał się skład orzekający (od licznych wyroków TSUE po Etykę nikomachejska Arystotelesa), jasności wniosków, pogłębionej argumentacji i wreszcie otwartej polemiki z wyrokami opisanymi we wcześniejszym akapicie niniejszego opracowania. Wobec ostatnich doktrynalnych sporów na temat zasadności istnienia instytucji opisanej w art. $70 \$ 6$ pkt 1 o.p. oraz jej nadużywania przez organy podatkowe wyrok ten powinien być punktem

${ }^{5}$ Wyrok NSA z dnia 30 października 2014 r., sygn. I FK 1505/13, LEX nr 1590680.

${ }^{6}$ Uchwała NSA z dnia 18 marca 2019 r., sygn. I FPS 3/18, ONSAiWSA 2019, nr 4, poz. 55. 
odniesienia dla organów podatkowych, sądów administracyjnych, a nawet ustawodawcy, ustalających wykładnię tego przepisu. W związku z tym warto poczynić kilka uwag dotyczących stanowiska wyrażonego przez WSA we Wrocławiu.

W pierwszej kolejności trzeba zwrócić uwagę na kwestię kompetencji sądu do weryfikacji zasadności wszczęcia przez organ przygotowawczy postępowania karnego skarbowego w sprawach o przestępstwa skarbowe. Dotychczas bowiem nie budziło w orzecznictwie większych wątpliwości, że przepis ustawy nie daje kompetencji do weryfikowania zasadności wszczęcia tego postępowania, w przedmiocie czego wypowiadał się Naczelny Sąd Administracyjny. Jak zauważono choćby w wyroku z dnia 23 lutego 2017 r. ${ }^{7}$, „przepis art. $70 \$ 6$ pkt 1 o.p. jako przyczynę powodującą zawieszenie biegu terminu przedawnienia zobowiązania podatkowego przewiduje wszczęcie postępowania w sprawie o przestępstwo skarbowe lub wykroczenie skarbowe, o którym podatnik został zawiadomiony, jeżeli podejrzenie popełnienia przestępstwa lub wykroczenia wiąże się z niewykonaniem tego zobowiązania. Unormowanie to nie daje podstaw prawnych do weryfikacji zasadności wszczęcia tego postępowania”. Skutkiem tego orzeczenia była bezzasadność zarzutów odnoszących się do przepisów Kodeksu karnego skarbowego. Stanowisko to zostało następnie nieco zliberalizowane w innym wyroku NSA, w którym zauważono, że zasadność mogłaby być badana w szczególnym przypadku umorzenia dochodzenia ${ }^{8}$. W kolejnych orzeczeniach sądy administracyjne wielokrotnie powtarzały swoje stanowisko w zakresie pozostawania zasadności wszczęcia postępowania karnego skarbowego poza ich kompetencją ${ }^{9}$ W dużej części z nich powoływano się właśnie na wyrok NSA z dnia 23 lutego 2017 r., w którym, jak wynika $\mathrm{z}$ uzasadnienia orzeczenia, przyjęty wniosek opierał się wyłącznie na wykładni literalnej art. $70 \$ 6$ pkt 1 o.p.

Taka wykładnia przepisów doprowadziła jednak do sytuacji, w której organy podatkowe, nie obawiając się kontroli sądów administracyjnych i ewentualnego zakwestionowania ich praktyk, zaczęły instrumentalnie traktować art. $70 \$ 6$ pkt 1 o.p., jako narzędzie niepozwalające na przedawnienie się zobowiązania podatkowego. Co więcej, jak wynika z danych

7 Wyrok NSA z dnia 23 lutego 2017 r., sygn. I FSK 1240/15, LEX nr 2249153.

8 Wyrok NSA z dnia 20 kwietnia 2018 r., sygn. II FSK 877/16, LEX nr 2500678.

9 Zob. wyrok NSA z dnia 16 lutego 2018 r., sygn. II FSK 220/16, LEX nr 2464988, czy wyrok NSA z dnia 10 sierpnia 2018 r., sygn. I GSK 2344/18, LEX nr 2558755. 
przedstawionych przez J. Waśko ${ }^{10}$, liczba postępowań karnych skarbowych wszczynanych w celu nieprzedawniania się zobowiązań podatkowych ma tendencję zwyżkową. W opinii zdecydowanej większości doktryny przyczyniło się to do tego, że przedawnienie - jako instytucja zapewniająca bezpieczeństwo podatników i pewność prawa - jest instytucją fikcyjną, gdyż jej ziszczenie się zależy od braku woli wszczęcia przygotowawczego postępowania karnego skarbowego przez organ podatkowy.

Z wyżej wskazanych powodów wyrok Wojewódzkiego Sądu Administracyjnego we Wrocławiu może zadowolić nie tylko podatników, ale i doradców podatkowych, głoszących wcześniej identyczne tezy. Sąd bowiem skonfrontował swój pogląd ze stanowiskiem przeważającej linii orzeczniczej, uważając, że niebadanie zasadności wszczęcia postępowania karnego skarbowego oznacza rezygnację przez sąd $\mathrm{z}$ udzielonej mu kompetencji, co prowadzi do niewypełniania standardu konstytucyjnego oraz unijnego w zakresie prawa do skutecznego środka prawnego i bezstronnego sądu. Ponadto zauważono, że ustawodawca, włączając pewne konstrukcje karne skarbowe do Ordynacji podatkowej, decyduje o tym, że stają się one częścią prawa podatkowego i jako takie powinny podlegać badaniu sądu administracyjnego.

Autor niniejszej glosy, jak zapewne zdecydowana większość doktryny, w pełni zgadza się z wnioskami WSA we Wrocławiu. Przeważająca do tej pory linia orzecznicza doprowadziła do sytuacji niedopuszczalnej, co zauważyli nawet projektodawcy nowej Ordynacji podatkowej ${ }^{11}$, podnosząc, że „możliwość zastosowania norm zawartych w prawie karnym skarbowym zależy [...] od ustaleń podjętych w toku rozstrzygania sprawy podatkowej m.in. w toku postępowania podatkowego i zakończonych decyzją wymiarową. $\mathrm{W}$ związku $\mathrm{z}$ tym brak jest podstaw do zawieszania biegu terminu przedawnienia wymiaru w prawie podatkowym $\mathrm{z}$ uwagi na wszczęcie postępowania w sprawie karnej skarbowej”. Tylko wykładnia przyjęta w glosowanym wyroku pozwala na ścisłe wypełnienie wyrażonej w art. 3 Prawa o postępowaniu przed sądami administracyjnymi ${ }^{12}$ funkcji sądów admini-

${ }^{10} \mathrm{~J}$. Waśko, Wszczynanie postępowań karnych skarbowych $w$ trakcie postępowań kontrolnych - analiza praktyki wybranych urzędów kontroli skarbowej, „Przegląd Podatkowy” 2017, nr 2, s. 44-49.

11 Projekt ustawy - Ordynacja podatkowa z dnia 6 października 2017 r., stworzony przez Komisję Kodyfikacyjną Ogólnego Prawa Podatkowego, pobrany ze strony internetowej Ministerstwa Finansów.

12 Ustawa $\mathrm{z}$ dnia 30 sierpnia 2002 r. Prawo o postępowaniu przed sądami administracyjnymi (tekst jedn. Dz.U. z 2018 r., poz. 1302 ze zm.), dalej: p.p.s.a. 
stracyjnych, tj. sprawowanie kontroli działalności administracji publicznej. Dotychczas sądy administracyjne, przeprowadzając wyłącznie wykładnię literalną przepisu, doprowadziły do sytuacji, w której sankcjonuje się nadużywanie prawa przez organy podatkowe. Jak jednak zauważył Naczelny Sąd Administracyjny w niedawnym wyroku ${ }^{13}$, „granice wykładni językowej nie są bezwzględne i ich przekroczenie uzasadnione jest w sytuacji odwołania się do wartości konstytucyjnych". W takim przypadku zasadne byłoby odniesienie się właśnie do aktów prawnych, na które powołano się w wyroku Wojewódzkiego Sądu Administracyjnego we Wrocławiu, takich jak Konstytucja RP, Konwencja o ochronie praw człowieka i podstawowych wolności czy Karta Praw Podstawowych Unii Europejskiej. Ponieważ autor podziela pogląd, że możność badania przez sądy zasadności wszczęcia postępowania karnego skarbowego wypełnia standard konstytucyjny, w całości zgadza się w tej kwestii z Sądem.

Kolejną istotną kwestią jest to, czy w istocie organ podatkowy, wszczynając postępowanie karne skarbowe, nadużył swoich kompetencji. Jak zauważono w uzasadnieniu glosowanego wyroku, nadużycie prawa w odniesieniu do organu podatkowego polega na przekroczeniu kompetencji, co ma nieporównywalnie większe znaczenie w przypadku, gdy dokonuje go organ podatkowy, gdyż podważany jest wówczas szacunek wobec porządku prawnego oraz organów władzy ${ }^{14}$. Próbę skonstruowania pełnej definicji nadużycia prawa podjął Bogumił Brzeziński, stwierdzając, że „nadużycie prawa podatkowego przez administrację podatkową to sytuacja, w której ma miejsce działanie administracji podatkowej wobec podatnika bez podstawy prawnej albo zastosowanie wadliwej podstawy prawnej, albo w oparciu o podstawę prawną wynikającą z bezzasadnej interpretacji prawa podatkowego"15. Zauważając przy tym szerokość definiowanego pojęcia, autor ten zastrzegł, iż cechą nadużycia jest brak efektywnych środków ochrony podatnika.

Choć jest to zagadnienie często opisywane w ostatnich latach w doktrynie prawa podatkowego, nie było ono praktycznie przedmiotem analizy sądów administracyjnych. Jak zauważyli A. Tałasiewicz i M. Goj ${ }^{16}$, tylko

13 Wyrok NSA z dnia 7 października 2019 r., sygn. I OSK 1499/08, LEX nr 746219.

${ }_{14} \mathrm{H}$. Filipczyk, Zakaz nadużycia prawa przez organy podatkowe, „Przegląd Podatkowy" 2019, nr 9, s. 18-25.

15 B. Brzeziński, O zjawisku nadużycia prawa podatkowego przez administrację skarbowa, „Kwartalnik Prawa Podatkowego” 2014, nr 1, s. 12-13.

16 A. Tałasiewicz, M. Goj, Od interpretacji po Kodeks karny skarbowy. Prawo czy praktyka - co decyduje o sukcesie?, [w:] Wspótczesne problemy prawa podatkowego - teoria 
w trzech wyrokach zostały zakwestionowane praktyki dokonywane przez organy podatkowe, mimo że zagadnienie było poruszane nawet w prasie codziennej. W wyrokach tych wskazano, że ze względu na brak realnego związku pomiędzy wszczęciem dochodzenia a niewykonaniem zobowiązania nie doszło do zawieszenia biegu terminu przedawnienia zobowiązania podatkowego ${ }^{17}$. W istocie jednak nie podjęto zagadnienia nadużywania prawa przez organy podatkowe, ograniczając się do sytuacji, gdy w momencie wszczęcia postępowania przygotowawczego doszło do przedawnienia karalności wykroczenia skarbowego.

Sąd w glosowanym wyroku zauważył, że w sprawie wszczęcie przygotowawczego postępowania karnego skarbowego nastąpiło półtora miesiąca przed upływem terminu przedawnienia, co jednak samo nie może przesądzać o przekroczeniu kompetencji. Odnotowano ponadto, że od momentu wszczęcia postępowania do wydawania wyroku przez Sąd minęło półtora roku i brak w tym okresie informacji o dalszym przebiegu postępowania - zwłaszcza że sprawa dotyczyła zagadnienia prawnego, jakim jest stawka w podatku od towarów i usług, a zatem nie wymagała przeprowadzania postępowania dowodowego.

W tej sytuacji sformułowany przez WSA we Wrocławiu test nadużycia wydaje się rewolucyjnie prosty i w istocie nie budzi większych wątpliwości. Jeśli organy podatkowe, działając w imieniu państwa, oczekują przestrzegania prawa podatkowego przez podatników i mogą kwestionować w określonych sytuacjach osiągnięcie przez niego korzyści podatkowej, to czymś zupełnie niezrozumiałym wydaje się nieoczekiwanie tego samego od organów podatkowych. Zagadnienie to było szeroko omawiane w doktrynie przy okazji przedstawiania projektu nowej Ordynacji podatkowej, w której początkowo znajdowała się zasada ogólna zakazująca nadużywania prawa przez organy podatkowe ${ }^{18}$. Niestety, biorąc pod uwagę dotychczasowe doświadczenia, rozwój pewnych tendencji (które przecież zostały zauważone przez prof. Brzezińskiego piętnaście lat temu) oraz doprowadzenie do usunięcia ogólnej zasady zakazu nadużywania prawa przez organy podatkowe nie jest dobrą zapowiedzią. Bez normatywnego wyrażenia zakazu nadużywania prawa przez organy podatkowe postulat ten może pozostać proponowanym

i praktyka. Ksiega jubileuszowa dedykowana Profesorowi Bogumiłowi Brzezińskiemu, t. 2, red. J. Głuchowski i in., Warszawa 2019, s. 292-302.

17 Wyrok NSA z dnia 24 listopada 2016 r., sygn. II FSK 148815, LEX nr 2190020.

18 B. Brzeziński, Zasady ogólne prawa podatkowego w projekcie nowej ordynacji podatkowej, „Przegląd Orzecznictwa Podatkowego” 2018, nr 3, s. 177-178. 
przez doktrynę postulatem, rzadko stosowanym przez sądy i wymagającym od nich dużej dozy odwagi, by przeciwstawić się ugruntowanym poglądom.

Wydaje się, że najbardziej kontrowersyjnym elementem glosowanego wyroku było odstąpienie od wykładni dokonanej przywoływaną już uchwałą składu 7 sędziów NSA z dnia 18 czerwca 2018 r. (sygn. I FPS 1/18), w której stwierdzono, że „zawiadomienie podatnika dokonane na podstawie art. 70c ustawy z dnia 29 sierpnia 1997 r. - Ordynacja podatkowa (Dz.U. z 2015 r., poz. 613 z późn. zm.) informujące, że z określonym co do daty dniem, na skutek przesłanki $z$ art. $70 \$ 6$ pkt 1 Ordynacji podatkowej nastąpiło zawieszenie biegu terminu przedawnienia zobowiązania podatkowego za wskazany okres rozliczeniowy, jest wystarczające do stwierdzenia, że nastąpiło zawieszenie biegu terminu przedawnienia tego zobowiązania na podstawie art. $70 \$ 6$ pkt 1 wyżej wskazanej ustawy”.

Istnieje jednak kilka problemów związanych z glosowanym wyrokiem. Należy w pierwszej kolejności zwrócić uwagę na problem ze stosowaniem przedmiotowego orzeczenia, które mimo swojej słuszności może mieć marginalne znaczenie w obrocie prawnym. Z całą pewnością podatnicy w ciągu najbliższych kilku miesięcy będą chętnie powoływać się na ów wyrok, często dopiero w odwołaniu od decyzji organu pierwszej instancji, który wszczął postępowanie karne skarbowe. Trudno sobie wyobrazić, że organ odwoławczy zauważy nadużycie prawa przez organ niższej instancji, stwierdzi przedawnienie zobowiązania podatkowego, a w konsekwencji umorzy postępowanie. Abstrahując od przyczyn organizacyjno-społecznych, organy podatkowe są zobowiązane działać, zgodnie $z$ art. 120 o.p., na podstawie przepisów prawa. W związku z tym, na podstawie jakiego przepisu organ odwoławczy mógłby (zakładając, że rozważy taką możliwość) uchylić decyzję organu niższego szczebla? Można próbować wyinterpretować taką możliwość, być może na podstawie pewnych zasad postępowania, ale bardzo trudno sobie to wyobrazić. Z kolei, gdy sprawa trafi do sądu administracyjnego, sędzia ma większe możliwości zmiany wyroku, lecz będzie to wymagało dużej odwagi od składu orzekającego i podjęcia ryzyka, że taki wyrok będzie uchylony przez sąd wyższej instancji.

W związku z powyższym wydaje się, że dopóki nie zostanie przyjęta nowa Ordynacja podatkowa albo inna normatywna podstawa przeciwdziałająca nadużywaniu prawa przez organy podatkowe, dopóty niewielka jest szansa na zmianę dotychczasowego trendu w orzecznictwie. Budzi to niestety obawy, że wyrok Wojewódzkiego Sądu Administracyjnego we Wrocławiu będzie chwalebnym, choć odosobnionym w swoich konkluzjach orzeczeniem. 
Innym zagadnieniem wywołującym wątpliwości jest kwestia ewentualnego naruszenia przez Sąd art. $269 \$ 1$ p.p.s.a. Przepis ten wskazuje, że jeżeli jakikolwiek skład sądu administracyjnego rozpoznający sprawę nie podziela stanowiska zajętego w uchwale składu 7 sędziów, całej Izby albo pełnego składu Naczelnego Sądu Administracyjnego, przedstawia powstałe zagadnienie prawne do rozstrzygnięcia odpowiedniemu składowi. W glosowanym wyroku, mimo niepodzielania poglądu wyrażonego w uchwale przez NSA, skład orzekający nie przedstawił sądowi wyższego szczebla zagadnienia do rozstrzygnięcia. Wbrew uchwale stwierdzono bowiem, że zawiadomienie wystosowane do podatnika na podstawie art. 70c o.p. nie informowało o wszystkich przyczynach wszczęcia postępowania karnego skarbowego, co naruszyło prawo podatnika do sądu, czego konsekwencją była niemożność prawidłowego sporządzenia skargi przez podatnika.

WSA we Wrocławiu uzasadnił swoje działanie zasadą pierwszeństwa prawa unijnego i zasadą skuteczności prawa unijnego. Podniesiono nawet, że zgodnie z wyrokiem Trybunału Sprawiedliwości Unii Europejskiej z dnia 20 października 2011 r. ${ }^{19}$ „prawo Unii sprzeciwia się temu, by sąd krajowy był związany krajowym przepisem proceduralnym, zgodnie z którym ocena sądu krajowego wyższej instancji jest dla niego wiążąca, gdy ocena owego sądu wyższej instancji jest niezgodna z prawem Unii w świetle wykładni Trybunału” (teza 39). Pośrednio zatem Sąd stwierdził, że przywołana uchwała NSA była sprzeczna z prawem unijnym, w związku z czym nie czuł się związany jej treścią. Drugą przyczyną niezwrócenia się do Naczelnego Sądu Administracyjnego wbrew art. $269 \$ 1$ p.p.s.a. był niedecydujący wpływ powyższego naruszenia na wynik sprawy, gdyż najistotniejsze było nadużycie prawa przez organ podatkowy.

Oceniając to stanowisko, można mieć pewne wątpliwości. Z jednej strony Sąd przytoczył wyroki, w których stwierdzono, że w razie dokonania przez skład powiększony NSA sprzecznej z przepisami unijnymi wykładni przepisów nie powinno się wszczynać procedury przewidzianej w art. 269 $\$ 1$ p.p.s.a. Potwierdzać to ma przytoczony wyrok w sprawie Interdil Srl, ale także wyrok Naczelnego Sądu Administracyjnego z dnia 27 czerwca 2013 r. $^{20}$ - ten ostatni dotyczy sytuacji, gdy dokonana przez skład poszerzony NSA wykładnia unijnych przepisów implementowanych do ustawodawstwa

19 Wyrok TSUE z dnia 20 października 2011 r., sygn. C-396/09, Interdil Srl in liquidation, v Fallimento Interedil and Inteas Gestione Crediti SpA, ECLI:EU:C:2011:671.

20 Sygn. I FSK 720/13, LEX nr POP 2014/2/150-157. 
krajowego pozostaje w sprzeczności z wykładnią tychże przepisów unijnej dyrektywy dokonaną przez TSUE. Z kolei w wyroku Naczelnego Sądu Administracyjnego z dnia 12 czerwca 2013 r. ${ }^{21}$ zauważono, że „sądy krajowe wykonując swoje obowiązki uprawnione są do pominięcia krajowych przepisów proceduralnych ograniczających uprawnienia przyznane im z mocy prawa unijnego".

Nie da się jednak ukryć, że wprowadza to pewien chaos do systemu prawnego. Można argumentować, że jest to dość niebezpieczna praktyka, gdyby bowiem żaden sąd nie czuł się związany uchwałą NSA, to jej wydawanie - mające na celu wzmacniać walor pewności prawa - stałoby się zbyteczne. $Z$ tej przyczyny uzasadnione mogą się wydawać obawy części komentatorów, że Wojewódzki Sąd Administracyjny we Wrocławiu poszedł zbyt daleko.

Niemniej, jak wskazano w wyroku, sprzeciw wobec uchwały nie dotyczył osi sporu, jakim jest nadużycie prawa przez organy podatkowe. W istocie Sąd nie musiał w ogóle podnosić swoich zastrzeżeń, gdyż nie miały one znaczenia dla wyniku sprawy, być może jednak chciano zaprotestować przeciwko uchwale sankcjonującej działania organów podatkowych ograniczające prawo do obrony. W związku $\mathrm{z}$ tym, mimo zakwestionowania zgodności z prawem uchwały NSA i nieprzedstawienia sprawy temu sądowi zgodnie z art. $269 \$ 1$ p.p.s.a., należy zgodzić się z Sądem. Wojewódzki Sąd Administracyjny we Wrocławiu, powołując się na niezgodność uchwały z prawem unijnym i odmawiając jej zastosowania, może sprowokować do szerszej niż do tej pory analizy przepisów, uwzględniającej przy tym nie tylko literalne brzmienie Ordynacji podatkowej, lecz także wartości wynikające z Konstytucji RP oraz prawa unijnego.

Podsumowując, glosowany wyrok jest słusznym i ważnym głosem w dyskusji na temat nadużywania prawa podatkowego przez organy w kontekście wszczynania postępowań karnych skarbowych. W opinii autora przedstawiono w nim szerszy kontekst związany z celami konstytucyjnymi oraz prawa unijnego instytucji opisanej w art. $70 \$ 6$ pkt 1 o.p., aniżeli do tej pory prezentowały sądy administracyjne. W związku z tym można tylko wyrażać nadzieję, że sądy w kolejnych wyrokach zaczną odważniej kwestionować praktyki organów podatkowych mogące naruszać prawa podatników.

${ }^{21}$ Sygn. I FSK 146/13, LEX nr 1376068. 


\section{BIBLIOGRAFIA}

Brzeziński B., O zjawisku nadużycia prawa podatkowego przez administracje skarbowa, „Kwartalnik Prawa Podatkowego” 2014, nr 1.

Brzeziński B., Zasady ogólne prawa podatkowego w projekcie nowej ordynacji podatkowej, „Przegląd Orzecznictwa Podatkowego" 2018, nr 3.

Filipczyk H., Zakaz nadużcia prawa przez organy podatkowe, „Przegląd Podatkowy” 2019, nr 9.

Tałasiewicz A., Goj M., Od interpretacji po Kodeks karny skarbowy. Prawo czy praktyka - co decyduje o sukcesie?, [w:] Wspótczesne problemy prawa podatkowego - teoria i praktyka. Ksiegga jubileuszowa dedykowana Profesorowi Bogumiłowi Brzezińskiemu, t. 2, red. J. Głuchowski i in., Warszawa 2019.

Waśko J., Wszczynanie postępowań karnych skarbowych w trakcie postępowań kontrolnych - analiza praktyki wybranych urzędów kontroli skarbowej, „Przegląd Podatkowy” 2017, nr 2.

\section{Gloss to the judgment of the Regional Administrative Court IN WrocŁAW OF 22TH JULY 2019 (I SA/Wr 365/19)}

Summary. Gloss elaborates the judgement of Regional Administrative Court in Wrocław, in which for the first time Court explicitly opposed against the practice of instrumentally initiating fiscal penal proceedings in order to suspend the period of limitation of a tax liability. What is new in the Polish jurisdiction, the Court concluded that validity of initiating fiscal penal proceedings should remain under court's jurisdiction. In abovementioned judgement issue of abuse of rights by the tax authority was developed, which was legal basis to annulment of the decision. A new versatile test of abuse of rights was proposed by the Court. In connection with the above, the author expressed hope that this judgement will be crucial and polish administrative courts will increasingly begin to question doubtful practices committed by the tax authorities.

Keywords: period of limitation, fiscal penal proceeding, abuse of rights, suspend the limitation period 